\title{
Reducing health inequity in Indonesia through a comprehensive training on social determinants of health among researchers and policy makers
}

\author{
Dwidjo Susilo ${ }^{1 *}$, Malin Eriksson ${ }^{2}$, Raman Preet $^{2}$, Siwi Padmawati ${ }^{3}$, Istiti Kandarina ${ }^{3}$, Laksono Trisnantoro ${ }^{3}$, \\ John Kinsman ${ }^{2}$
}

From 7th Postgraduate Forum on Health Systems and Policies

Phitsanulok, Thailand. 24-25 June 2013

\section{Background}

Indonesia is a country with great disparities, geographically, demographically, and economically. The implementation of decentralisation had a tremendous impact on the national health system. Since the effective development and implementation of all policies depended on the capability of the heads of districts, these conditions influenced the health of the Indonesian people. In addition, it also brought about health inequity in Indonesia. This study aimed to provide a situation analysis for Indonesia, focusing on the current social determinants of health-related (SDH-related) training in Indonesia, and gaps identified.

\section{Materials and methods}

Information on SDH-related curricula at public health schools was collected through using search engines on the internet. We also interviewed 15 key informants at national and local levels to develop a better insight of $\mathrm{SDH}$ issues in Indonesia. They were categorised as decision-makers, donors, NGOs, WHO, and SDH experts. Informants were interviewed using a 'category-specific' interview guide that was produced by a team at Umea University.

\section{Results}

The terms 'social determinants of health' (SDH) were not widely used or understood in Indonesia. SDH was not taught explicitly in any graduate schools of public health in Indonesia. SDH was taught as only a component of different courses. There were also a very limited number of seminars on SDH in Indonesia. The knowledge of SDH was very inadequate, but not limited among those who work in the health sector, but also those working in other sectors. National level data and regulations were insufficient to effectively address SDH, but rather data and interventions are needed at district level.

\section{Conclusions}

There are currently no SDH-specific courses available, although SDH-related topics are included in some of the existing courses at the public health schools. Intensive and more structured training on SDH is needed in order to ensure a good understanding of SDH in Indonesia among key research and policy stakeholders in all sectors and at all levels.

\section{Authors' details}

'Universitas Muhammadiyah Jakarta, Jakarta 15419, Indonesia. ${ }^{2} U m e a$ University, 90187 Umea, Sweden. ${ }^{3}$ Universitas Gadjah Mada, Yogyakarta 55281, Indonesia.

Published: 29 January 2014

doi:10.1186/1471-2458-14-S1-O2

Cite this article as: Susilo et al:: Reducing health inequity in Indonesia through a comprehensive training on social determinants of health among researchers and policy makers. BMC Public Health 2014

14(Suppl 1):O2.

* Correspondence: dsusilo@gmail.com

${ }^{1}$ Universitas Muhammadiyah Jakarta, Jakarta 15419, Indonesia

Full list of author information is available at the end of the article 